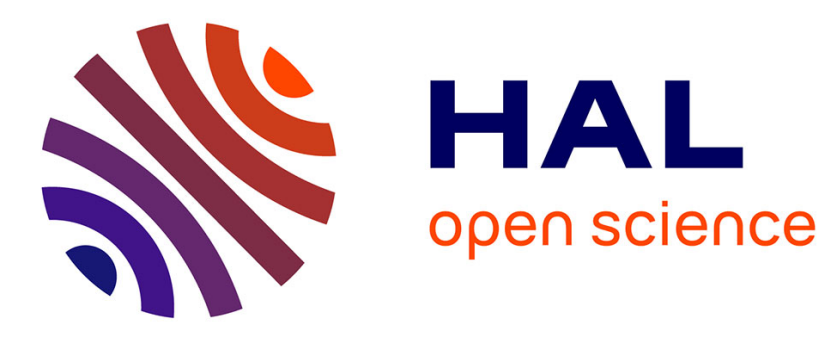

\title{
Hypopituitarism in Patients with Blepharophimosis and FOXL2 Mutations
}

\author{
Sarah Castets, Florence Roucher-Boulez, Alexandru Saveanu, Delphine \\ Mallet-Motak, Olivier Chabre, Patrizia Amati-Bonneau, Dominique Bonneau, \\ Celine Girardin, Yves Morel, Carine Villanueva, et al.
}

\section{To cite this version:}

Sarah Castets, Florence Roucher-Boulez, Alexandru Saveanu, Delphine Mallet-Motak, Olivier Chabre, et al.. Hypopituitarism in Patients with Blepharophimosis and FOXL2 Mutations. Hormone Research in Paediatrics, 2020, 93 (1), pp.30-39. 10.1159/000507249 . hal-03223181

\section{HAL Id: hal-03223181 \\ https://hal-amu.archives-ouvertes.fr/hal-03223181}

Submitted on 11 May 2021

HAL is a multi-disciplinary open access archive for the deposit and dissemination of scientific research documents, whether they are published or not. The documents may come from teaching and research institutions in France or abroad, or from public or private research centers.
L'archive ouverte pluridisciplinaire HAL, est destinée au dépôt et à la diffusion de documents scientifiques de niveau recherche, publiés ou non, émanant des établissements d'enseignement et de recherche français ou étrangers, des laboratoires publics ou privés. 


\title{
Hypopituitarism in Patients with Blepharophimosis and FOXL2 Mutations
}

\author{
Sarah Castets ${ }^{a, b}$ Florence Roucher-Boulez ${ }^{c, d, e}$ Alexandru Saveanu ${ }^{b, f}$ \\ Delphine Mallet-Motakc, ${ }^{c}$ Olivier Chabreg Patrizia Amati-Bonneau ${ }^{\text {h, }} \mathrm{i}$ \\ Dominique Bonneau $^{h, i}$ Celine Girardin ${ }^{j}$ Yves Morel, e Carine Villanueva ${ }^{a, d}$ \\ Thierry Brue ${ }^{b, f}$ Rachel Reynaud ${ }^{b, f}$ Marc Nicolino a, d,e

\begin{abstract}
aHospices Civils de Lyon, Hôpital Femme Mère Enfant, Service d'Endocrinologie Pédiatrique, Bron, France;
${ }^{b}$ Aix-Marseille Université, AP-HM, Centre de Référence des Maladies Rares D'origine Hypophysaire HYPO, Marseille, France; ' ${ }^{C}$ Hospices Civils de Lyon, Groupement Hospitalier Est, Laboratoire de Biochimie et Biologie Moléculaire Grand Est, UM Pathologies Endocriniennes Rénales Musculaires et Mucoviscidose, Bron, France; ${ }^{d}$ Centre de Référence du Développement Génital: du Fœtus à l'Adulte, Filière Maladies Rares Endocriniennes, Bron, France; ${ }^{e}$ Univ Lyon, Université Claude Bernard Lyon 1, Lyon, France; ${ }^{f}$ Aix Marseille Université, INSERM, MMG, U 1251, Marseille, France; ${ }^{9} \mathrm{CHU}$ de Grenoble Alpes et Université Grenoble Alpes, CS 10217 38043, Service d'Endocrinologie, Grenoble, France; ${ }^{\text {h}}$ MitoLab Team, UMR CNRS 6015 - INSERM U1083, Institut MitoVasc, Université et Hôpital d'Angers, Angers, France; 'Département de Biochimie et Génétique, Université et Hôpital $\mathrm{d}^{\prime}$ Angers, Angers, France; ${ }^{j}$ Hôpitaux Universitaires de Genève, Endocrinologie Pédiatrique, Genève, Switzerland
\end{abstract}

\section{Keywords}

Blepharophimosis · Hypopituitarism · Growth hormone deficiency · Ocular anomalies · FOXL2

\footnotetext{
Abstract

Background: FOXL2 is the gene involved in blepharophimosis, ptosis, and epicanthus inversus syndrome (BPES). There have been few single case reports of growth hormone deficiency (GHD) with this syndrome, and Fox/2 is known to be involved in pituitary development in mice. Our aim was to analyze the prevalence of FOXL2 gene alteration in a series of patients with congenital hypopituitarism and eyelid anomalies. Methods: FOXL2 was analyzed in 10 patients with hypopituitarism (ranging from isolated GHD to complete pituitary hormone deficiency) and eyelid anomalies (typical
}

BPES in 4 patients and milder anomalies in 6 patients). In patients with an FOXL2 mutation, we ruled out other possible molecular explanations by analyzing a panel of 20 genes known to be associated with hypopituitarism, and a candidate gene approach was used for patients without an FOXL2 mutation. Results: Three patients had an FOXL2 mutation. All 3 had typical BPES. Their pituitary phenotype varied from GHD to complete pituitary hormone deficiency and their pituitary morphology ranged from normal to an interrupted pituitary stalk. No mutations were found in genes previously associated with hypopituitarism. Conclusion: Our study shows that some patients with BPES have hypopituitarism with no molecular explanation other than FOXL2 mutation. This points toward an involvement of FOXL2 in human pituitary development. 


\section{Introduction}

Congenital hypopituitarism is a rare disease characterized by isolated or multiple pituitary hormone deficiencies. This condition is diagnosed once other causes of organic hypopituitarism, such as tumors, have been excluded. It can be induced by mutations of genes coding for transcription factors involved in pituitary development [1]. This rare disease may reveal structural anomalies in the hypothalamic-pituitary region and is sometimes associated with extrapituitary anomalies [2].

Our knowledge of the molecular causes of congenital hypopituitarism has improved in recent years [3, 4]. Studies of patients with associated extrapituitary malformations, notably of the eyes, can point toward new candidate genes. Thereby, the genes HESX1 (septo-optic dysplasia; OMIM [Online Mendelian Inheritance in Man] No. 182230) [5], OTX2 (Axenfeld-Rieger syndrome: ectopic iris, polycoria, and sometimes glaucoma) [6], SOX2 (anophthalmia or severe microphthalmia) [7], PROKR2 (septo-optic dysplasia) [8], FGFR1 (septo-optic dysplasia) [9], and ARNT2 (blindness and neurological and renal diseases) [10] are now known to be implicated in hypopituitarism with eye anomalies. However, a molecular cause is only found in a minority of cases of congenital hypopituitarism, with previous studies identifying proportions of about $10 \%$ in Western Europe [3] and 30\% in Eastern Europe [11]. This suggests that other factors involved in hypothalamopituitary development remain to be discovered.

FOXL2 encodes a transcription factor from the forkhead family involved in embryonic development and is expressed by cranial neural crest cells and cranial mesodermal cells which give rise to the skeletal and muscular components of the head [12]. FOXL2 is a protein of 367 amino acids composed of a DNA-binding forkhead domain and a polyalanine tract of unknown function [13]. Mutations in FOXL2 cause blepharophimosis, ptosis, and epicanthus inversus syndrome (BPES; OMIM No. 110100), an autosomal dominant genetic disorder responsible for eyelid anomalies (a narrowing of the eye opening and an upward fold of the skin of the lower eyelid near the inner corner of the eye) and premature ovarian failure [14]. FOXL2 plays an essential role in maintaining ovarian identity in humans, with haploinsufficiency blocking follicle development [15]. Damage to the gonads is not systematic with BPES; however, female patients with type 1 BPES have premature ovarian failure, while female patients with type 2 BPES maintain normal gonadal function [16]. Other ocular malformations, such as lacrimal duct anomalies, strabismus, amblyopia, or defective refraction, may also arise [17]. A number of other morphological features (including a wide nasal bridge, low-set ears, and a short philtrum) and a few rare cases of cardiomyopathy and psychomotor retardation have more rarely been associated with FOXL2 mutations [18]. FOXL2 is also involved in pituitary function, as indicated by its expression in mouse gonadotrophs and thyreotropes and human gonadotrophs [19] and the altered gonadotropic and somatotropic function of mutant mice $[19,20]$. Interestingly, there have been 5 reported cases of BPES patients with growth hormone deficiency (GHD) $[13,21,22]$. The aim of this study was therefore to understand the role of FOXL2 in patients with hypopituitarism and eyelid anomalies.

\section{Method}

This was an observational analytical study involving the Pediatric Endocrinology Departments of the Hôpital Femme Mère Enfant (rare disease reference center for pituitary disorder DEHFY, Lyon, France), the Hôpital de la Timone (rare disease reference center for pituitary disorder HYPO, Marseille, France), and the Hôpitaux Universitaires de Genève (Geneva, Switzerland).

Patients

The inclusion criteria were: (1) GHD suggested by a short stature $<-2$ SD and/or a low growth rate $<-1$ SD for children, and a stimulated peak $\mathrm{GH}$ level $<10 \mu \mathrm{g} / \mathrm{L}$, in isolation or associated with other pituitary hormone deficiencies, and (2) eyelid anomalies, including typical BPES or milder eyelid anomalies such as isolated blepharophimosis, isolated ptosis, or isolated epicanthus inversus.

Genetic Analysis

Patients or their parents provided informed written consent for the genetic analysis.

FOXL2 was sequenced and analyzed by multiplex ligation-dependent probe amplification (MLPA) in 10 patients with hypopituitarism and eyelid anomalies.

In patients with an FOXL2 mutation, we performed next-generation sequencing (NGS) targeting a panel of genes known to be associated with combined pituitary hormone deficiency or isolated GHD, i.e., ARNT2, FGF8, FGFR1, GH1, GHRHR, GHSR, GLI2, HESX1, IGSF1, LHX3, LHX4, OTX2, PAX6, PROP1, POU1F1, PROKR2, RNPC3, SOX3, SOX2, and TBX19.

In patients with no FOXL2 mutation, FGFR1, GH1, GHRH, GLI2, HESX1, LHX3, LHX4, OTX2, PROP1, POU1F1, PROKR2, and $S O X 3$ were investigated by Sanger sequencing using a candidate gene approach, based on clinical and radiological phenotype data from the literature [2].

Molecular Genetic Analysis of the FOXL2 Gene

Sanger Sequencing. Genomic DNA was extracted from EDTApreserved whole blood using a Nucleon BACC3 Kit (GE healthcare, Chalfont Saint Giles, Buckinghamshire, UK).

The coding exon of the FOXL2 gene was selectively amplified in 2 fragments by PCR using specific primers (available on request). The exons and exon-intron boundaries were sequenced 
Table 1. Clinical, biological, radiological, and genetic characteristics of the patients

\begin{tabular}{|c|c|c|c|c|c|}
\hline $\begin{array}{l}\text { Patient } \\
\text { No. }\end{array}$ & Ocular phenotype & $\begin{array}{l}\text { Pituitary } \\
\text { deficiency }\end{array}$ & Extrapituitary anomalies & MRI & Genetic \\
\hline 1 & BPES & $\begin{array}{l}\text { GH, TSH, } \\
\text { ACTH }\end{array}$ & $\begin{array}{l}\text { Ogival palate, low-set ears, dental embedding } \\
\text { anomalies }\end{array}$ & $\begin{array}{l}\text { APH, Chiari type } 1 \text {, } \\
\text { syringomyelia }\end{array}$ & FOXL2+, NGS- \\
\hline 2 & BPES & GH & None & PSIS & FOXL2+, NGS- \\
\hline 3 & BPES & $\begin{array}{l}\text { GH, TSH, } \\
\text { ACTH, } \\
\text { LH-FSH }\end{array}$ & None & Normal & FOXL2+, NGS- \\
\hline 4 & $\begin{array}{l}\text { BPES, strabismus, } \\
\text { amblyopia }\end{array}$ & $\begin{array}{l}\text { GH, TSH, } \\
\text { ACTH, } \\
\text { LH-FSH }\end{array}$ & $\begin{array}{l}\text { Renal hypoplasia, plagiocephaly, macrocephaly, } \\
\text { retrognathia, mild developmental delay, feeding } \\
\text { problems, balance problems }\end{array}$ & PSIS & $\begin{array}{l}\text { FOXL2-, HESX1-, } \\
\text { OTX2-, PROKR2-, } \\
\text { LHX4-, SOX3-, } \\
\text { ARNT2- }\end{array}$ \\
\hline 5 & Blepharophimosis & $\mathrm{GH}, \mathrm{ACTH}$ & $\begin{array}{l}\text { POF, CHD, congenital muscular torticollis and } \\
\text { metatarsus varus, developmental delay }\end{array}$ & Normal & FOXL2- \\
\hline 7 & $\begin{array}{l}\text { Blepharophimosis, } \\
\text { ptosis }\end{array}$ & $\mathrm{GH}, \mathrm{TSH}$ & Hyperlaxity, obesity, developmental delay & $\begin{array}{l}\text { APH, ventricular } \\
\text { dilatation, periventricular } \\
\text { heterotopia }\end{array}$ & $\begin{array}{l}\text { FOXL2-, HESX1-, } \\
\text { OTX2-, PROP1-, } \\
\text { LHX3-, POU1F1- }\end{array}$ \\
\hline 8 & $\begin{array}{l}\text { Blepharophimosis, } \\
\text { cataract }\end{array}$ & $\begin{array}{l}\text { GH, TSH, } \\
\text { ACTH, } \\
\text { LH-FSH }\end{array}$ & $\begin{array}{l}\text { CHD, feeding problems, anemia, cholesteatoma, } \\
\text { Hirshsprung disease, spondyloepiphyseal dysplasia, } \\
\text { encephalitis, fistula auris, ogival palate, genu valgum, } \\
\text { dental agenesia, pectus excavatum }\end{array}$ & $\begin{array}{l}\text { APA withe and grey } \\
\text { matter anomalies }\end{array}$ & $\begin{array}{l}\text { FOXL2-, HESX1-, } \\
\text { OTX2-, LHX3-, } \\
\text { GLI2- }\end{array}$ \\
\hline 9 & $\begin{array}{l}\text { Blepharophimosis, } \\
\text { epicanthus inversus }\end{array}$ & GH & Double incisor tooth & $\mathrm{APH}$ & $\begin{array}{l}\text { FOXL2-, HESX1-, } \\
\text { OTX2-, GH1-, } \\
\text { GHRHR-, GLI2-, } \\
\text { FGFR1- }\end{array}$ \\
\hline
\end{tabular}

APA, anterior pituitary aplasia; APH, anterior pituitary hypoplasia; CC, corpus callosum; CHD, congenital hip dysplasia; ONH, optic nerve hypoplasia; POF, premature ovarian failure; PSIS, pituitary stalk interruption syndrome; SOD, septo-optic dysplasia; SP, septum pellucidum.

conventionally using the Sanger dideoxy technique and Big-Dye terminators. The sequencing products were loaded onto an ABI3730XL sequencer and analyzed using the software SeqScape v3 (Thermofisher Scientific, Watham, MA, USA). Sequence variants were designated according to Human Genome Society recommendations (www.hgvs.org/rec.html) using the NCBI reference sequences NC_000003.11, NM_023067.3, and NP_075555.1 built on the GRCh37/hg19 human genome.

Multiplex Ligation-Dependent Probe Amplification. In order to detect duplications or deletions, MLPA analysis was performed using a SALSA P054-C1-FOXL2-TWIST1 Probemix Kit (MRC Holland, Amsterdam, The Netherlands).

Molecular Genetic Analysis of the Genes Involved in Pituitary Development

NGS and Analysis. Genomic DNA was extracted with a QiaSymphony DS DNA Midi Kit (Qiagen ${ }^{\circledR}$, France) from blood lymphocytes (standard EDTA samples). Exons and 20-bp flanking introns of 20 genes confirmed as causal in combined pituitary hormone deficits and/or isolated growth hormone (GH) deficits (ARNT2, FGF8, FGFR1, GH1, GHRHR, GHSR, GLI2, HESX1, IGSF1, LHX3, LHX4, OTX2, PAX6, PROP1, POU1F1, PROKR2, RNPC3 SOX3, SOX2, and TBX19) were amplified using a QIAseq Targeted DNA Custom Panel (Qiagen ${ }^{\circledR}$ ).

The preparation of the library was completed according to the manufacturer's instructions. All sample preparations were then sequenced on MiseqDx (Miseq V2 Reagent Kit; 500 cycles) (Illumina ${ }^{\circledR}$, San Diego, CA, USA). Data issued from sequencing were exported and further analyzed (base calling, read filtering, alignment with the human genome; GRCH37/hg19) and annotated using Biomedical Genomic Workbench v4.1.1. software (Qiagen GmbH, Hilden, Germany). Variant calling analysis was completed on VariantStudio v2.2 (Illumina ${ }^{\circledR}$ ). All of the regions targeted had a depth of coverage above $30 \times$ ( 16 samples in a run).

All variants of interest were visually inspected in the Integrative Genomics Viewer (https://www.broadinstitute.org/igv) to evalu- 


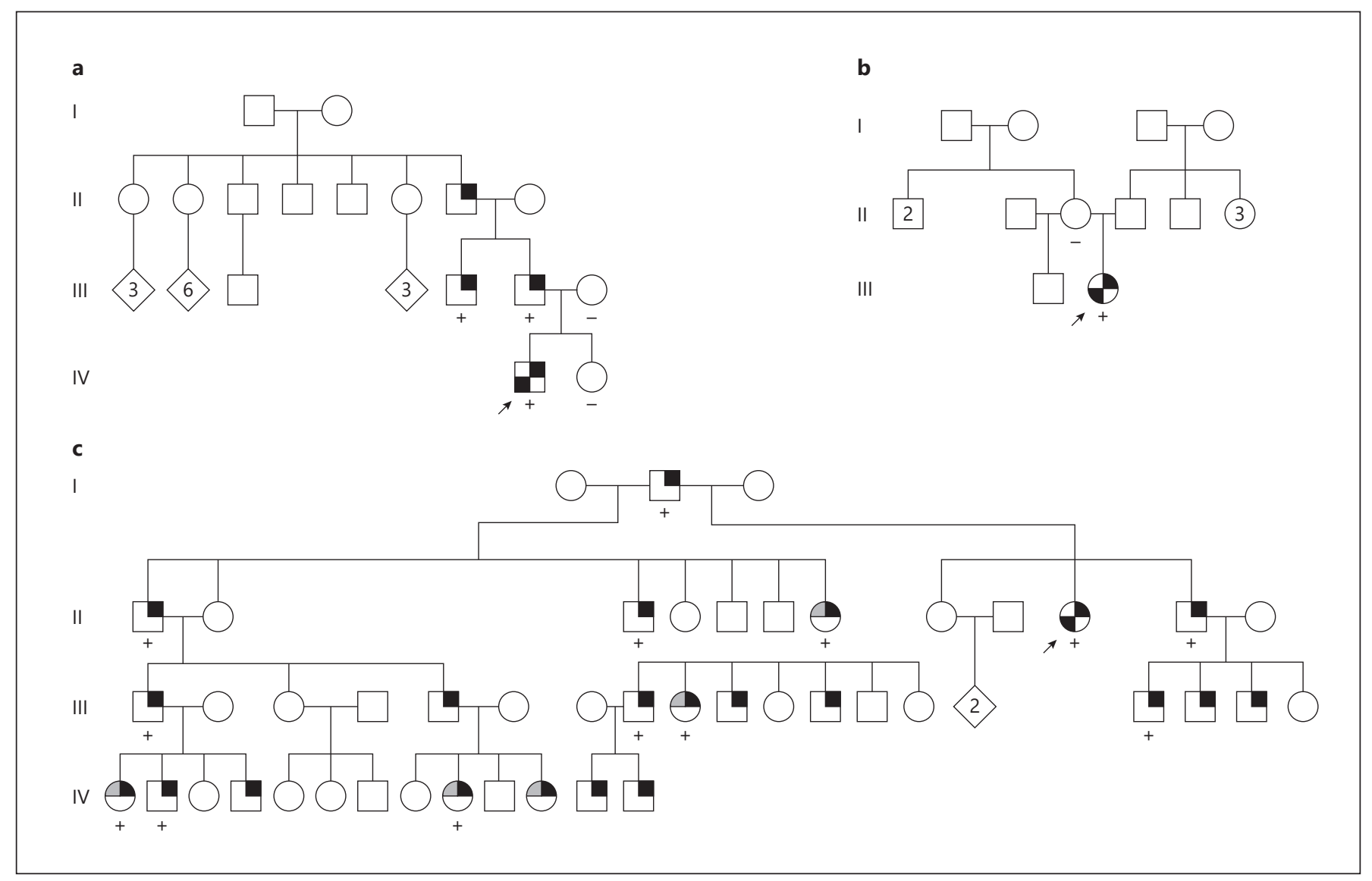

Fig. 1. Pedigrees and respective FOXL2 mutations for patients 1 (c855_871dup) (a), 2 (c.675_1008del) (b), and 3 (c.611G $>$ A) (c). Index patients are indicated by an arrow. Affected individuals are indicated by closed symbols; BPES is indicated by a black square in the right upper part of the symbol, primary ovarian insufficiency is indicated by a grey square in the left upper part of the symbol, and hypopituitarism is indicated by a black square in the left lower part of the symbol. Individuals who tested positive for FOXL2 are indicated by a+, and those who tested negative are indicated by a-.

ate the mapping and variant calling quality. The variants were then classified into 5 main categories using American College of Medical Genetics and Genomics guidelines, i.e., pathogenic, likely pathogenic, variants of uncertain clinical significance, likely benign, and benign.[23]

\section{Results}

The clinical characteristics of the patients in this cohort are presented in Table 1.

Our cohort included 10 patients (patients 1-10) with hypopituitarism and eyelid anomalies. Four had typical BPES. The eyelid anomalies of the other 6 were less severe, i.e., blepharophimosis, ptosis, and epicanthus inversus in association or isolation. The pituitary phenotypes ranged from isolated GHD to complete hypopituitarism.
Structural pituitary anomalies were identified for 8 of the patients, and these ranged from isolated adenohypophyseal hypoplasia to pituitary stalk interruption syndrome (PSIS).

Three out of 10 patients had loss-of-function FOXL2 mutations (patients 1-3 in Table 1; family trees in Fig. 1):

Patient 1 was found to carry the mutation c855_871dup or p.(His291Argfs*71). At the protein level, the forkhead domain should be unmodified as the polyalanine tract, but the C-terminus is completely modified. (Fig. 2). Frequency databases (dbSNP and gnomAD) were searched to determine whether the variant had already been reported. It has a dbSNP ID because it is reported in ClinVar as a pathogenic variant. It was not reported in control databases such as GnomAD. This mutation has already been described and is reported in the LOVD database 


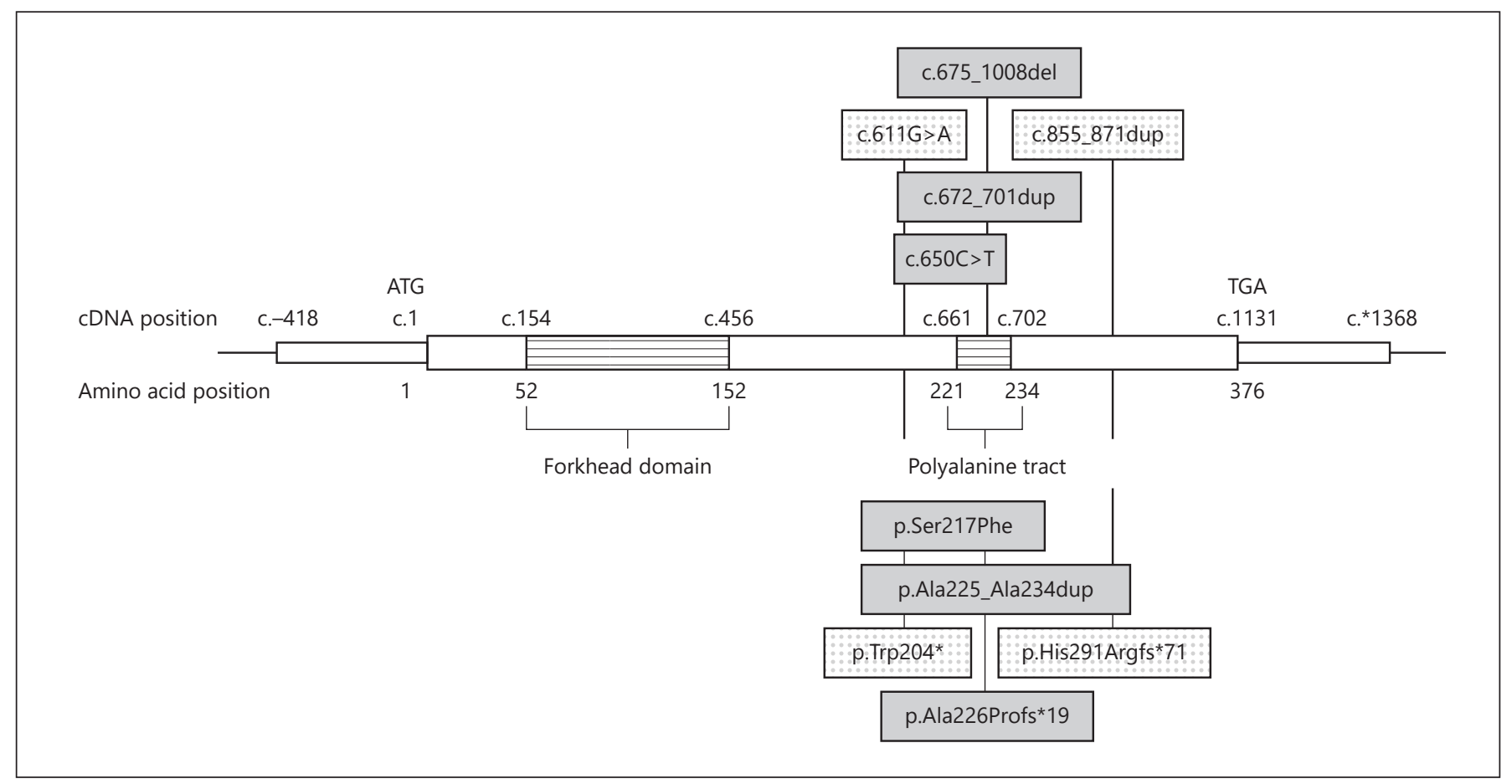

Fig. 2. FOXL2 mutations. The FOXL2 coding sequence is the central portion of the figure. The mutations detected in our 3 patients are in bold, at the cDNA level above and at the protein level below the sequence; the mutations described in the literature are in regular font. The grey boxes indicate isolated GHD and the dotted boxes indicate complete pituitary hormone deficiency.

Table 2. Hypopituitarism in BPES patients

\begin{tabular}{|c|c|c|c|c|c|}
\hline Study & BPES & Clinical information & MRI & Molecular analysis & Predicted protein change \\
\hline Wales [21] & $\begin{array}{l}\text { Familial, } \\
\text { type } 2\end{array}$ & $\begin{array}{l}\text { GHD in an } \\
11 \text {-year-old boy }\end{array}$ & Pituitary hypoplasia & None & NA \\
\hline $\begin{array}{l}\text { Varghese et al. } \\
\text { [22] }\end{array}$ & $\begin{array}{l}\text { Familal, } \\
\text { type unknown }\end{array}$ & $\begin{array}{l}\text { GH deficiency in a } \\
14 \text {-year-old boy }\end{array}$ & $\begin{array}{l}\text { Atrophic anterior } \\
\text { pituitary }\end{array}$ & NA & NA \\
\hline $\begin{array}{l}\text { Beysen et al. } \\
{[13]}\end{array}$ & $\begin{array}{l}\text { Familial, } \\
\text { type unkown }\end{array}$ & $\begin{array}{l}\text { GH deficiency in } \\
2 \text { sisters }\end{array}$ & & $\begin{array}{l}\text { c.650C>T } \\
\text { (family FOXL2_00087) }\end{array}$ & $\begin{array}{l}\text { AA substitution downstream } \\
\text { of the forkhead domain }\end{array}$ \\
\hline This study & $\begin{array}{l}\text { Familial, } \\
\text { type unknown }\end{array}$ & $\begin{array}{l}\text { GH, ACTH, and } \\
\text { TSH deficiency in a } \\
10 \text {-year-old boy } \\
\text { Facial dysmorphia } \\
\text { and dental anomalies }\end{array}$ & $\begin{array}{l}\text { Adenohypophyseal } \\
\text { hypoplasia } \\
\text { Type } 1 \text { Chiari } \\
\text { malformation } \\
\text { Syringomyelia }\end{array}$ & c855_871dup & $\begin{array}{l}\text { Truncated protein with a } \\
\text { complete forkhead domain } \\
\text { and polyalanine tract but a } \\
\text { completely modified C-terminus }\end{array}$ \\
\hline This study & $\begin{array}{l}\text { Familial, } \\
\text { type } 1\end{array}$ & $\begin{array}{l}\text { GH, TSH, ACTH, } \\
\text { LH-FSH deficiency } \\
\text { in a woman }\end{array}$ & $\begin{array}{l}\text { Normal hypophyseal } \\
\text { region }\end{array}$ & c. $611 \mathrm{G}>\mathrm{A}$ & Truncated polyalanine tract \\
\hline
\end{tabular}

Cases reported to date are shown. NA, not available. 


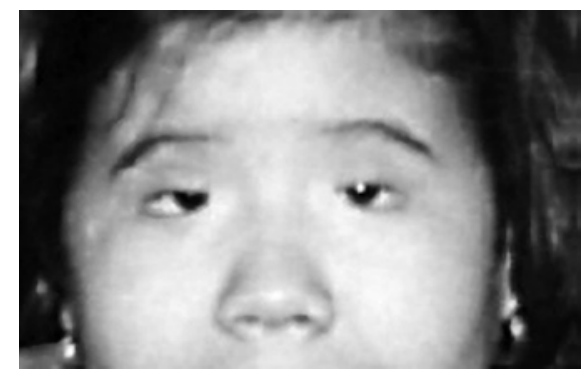

Fig. 3. Photograph of patient 1 with typical BPES.

(https://lovd.cmgg.be/index.php?select_db=FOXL2) but not in the HGMD (free version) [14, 24, 25]. According to the ACMG/AMP standard guidelines [23] the variant is classified as pathogenic (Table 2). This patient had typical hereditary BPES (Fig. 3), as well as facial dysmorphia (ogival palate and low-set ears) and dental embedding anomalies. The birth size was normal, but then growth stunting down to -2 SD from the median and delayed bone maturation occurred, leading to a diagnosis of severe GHD at the age of 10 years (decreased IGF1 and IGFBP3 and stimulated GH peaks at 2.3 and $2.4 \mu \mathrm{g} / \mathrm{L}$ after ornithine and propranolol-glucagon, respectively), associated with partial TSH and ACTH deficiencies. Magnetic resonance imaging (MRI) revealed adenohypophyseal hypoplasia, a type 1 Chiari malformation and C5 to C7 syringomyelia. He responded particularly well to L-thyroxin and $\mathrm{GH}$ treatment, gaining $4.5 \mathrm{SD}$ in total and growing to a final height in accordance with the midparental target. His treatment has been maintained into adulthood because of persisting GH deficiency. No pathogenic variant was found in the panel of 20 hypopituitarism-associated genes. The patient's father, paternal uncle, and grandfather also had BPES. No other family member is known to have hypopituitarism. FOXL2 was analyzed in 5 members of the family, and mutations were only found in 3 patients with BPES (Fig. 1).

Patient2 wasfound to carrythemutationc.675_1008del. This deletion of $334 \mathrm{bp}$ leads to a frameshift mutation (p.Ala226Profs*19). This leaves the forkhead domain intact but the polyalanine tract is truncated. (Fig. 2). This variant is not reported in any database to date (dbSNP, gnomAD, ClinVar, and HGMD), but this region is not well sequenced in the control databases by exome or genome sequencing. According to ACMG/AMP standard guidelines [23] the variant is classified as pathogenic (Table 2). No FOXL2 mutations were found in the patient's mother; the patient's father refused to be tested. She has typical BPES without dysmorphia. Her family history is unremarkable. Her gonadotropin levels are currently not elevated at the age of 8 years. Specific pituitary function tests were performed at the age of 5 years despite the absence of symptoms, specifically to investigate the possible association with GHD. Isolated partial GHD, i.e., a low normal IGF1 level $(94 \mu \mathrm{g} / \mathrm{L}$; reference range for age and Tanner stage 85.9-152.6 $\mu \mathrm{g} / \mathrm{L})$, a GH concentration peak at $4.6 \mu \mathrm{g} / \mathrm{L}$ after clonidine stimulation, was identified. MRI showed PSIS with a very thin barely visible stalk, adenohypophyseal hypoplasia $(1 \mathrm{~mm})$, and an ectopic neurohypophysis. This patient had not yet been treated with $\mathrm{GH}$ at the time of reporting because her growth velocity had so far remained normal. No pathogenic variant was found in the panel of 20 hypopituitarism-associated genes. No other family members had BPES or hypopituitarism. FOXL2 was only analyzed in the patient's mother, and no mutation was found.

Patient 3 was found to carry the mutation c.611G>A or p.(Trp204*) (Fig. 2). It is a nonsense mutation that truncates the protein (p.Trp204*), leaving the forkhead domain intact, but with a deletion of the polyalanine tract. The variant is not identified in control population databases such as GnomAD but has already been described and is reported in the LOVD (https://lovd.cmgg. be/index.php? select_db = FOXL2) and HGMD databases. According to ACMG/AMP standard guidelines [23] the variant is classified as pathogenic (Table 2). The patient has typical hereditary BPES and hypogonadism with, unexpectedly, low gonadotrophin levels. This led to exploration of her pituitary function, which revealed severe GHD (peak concentration after insulin-induced hypoglycemia at $0.3 \mu \mathrm{d} / \mathrm{L}$ ), TSH deficiency (normal TSH, low T4 level at $11.1 \mathrm{pmol} / \mathrm{L}$, normal range $>11.5 \mathrm{pmol} / \mathrm{L}$ ) and partial ACTH deficiency (cortisol peak concentration after insulin-induced hypoglycemia, $14,5 \mu \mathrm{g} / \mathrm{dL}$; repeated 8:00 a.m. cortisol levels of about $5 \mu \mathrm{g} / \mathrm{dL}$ during follow-up). MRI showed a normal hypophyseal region. She had reached a normal adult height without GH treatment, and hormone substitution was initiated upon diagnosis of hypopituitarism at the age of 47 years. Several members of the family also have BPES, and all the other BPES females have premature ovarian insufficiency with elevated gonadotrophins typically associated with BPES type 1 . The FOXL2 mutation was identified in $11 \mathrm{mem}-$ bers of the family, and in one other member linkage analysis revealed cosegregation with the disease phenotype (the analysis for this patient was performed before FOXL2 was known).

None of the 3 patients with FOXL2 mutations and hypopituitarism (patients 1-3) was found to have patho- 
genic or likely pathogenic variants in hypopituitarismassociated genes.

No pathogenic or likely pathogenic variants in FOXL2 or the hypopituitarism-associated genes were found in the remaining 7 patients.

\section{Discussion}

This is the first reported case series of BPES patients with hypopituitarism and an FOXL2 mutation. A complete molecular analysis of hypopituitarism-related genes was performed by NGS and Sanger sequencing.

These results indicate that FOXL2 mutations can be associated with congenital hypopituitarism in patients with BPES. This has already been suggested by a few single case reports in the literature $[13,21,22]$, but our study is the first that formally implicates FOXL2 in hypopituitarism (Table 2). Wales [21] described isolated GHD with pituitary hypoplasia in an 11-year-old boy with BPES without associating it with a molecular cause [21]. Varghese et al. [22] reported the case of a 14-year-old boy with BPES, isolated GHD since early childhood, and an atrophic anterior pituitary gland [22]. Crisponi et al. [14] described a patient with BPES and growth retardation but did not test his somatotropic function. More recently, Beysen et al. [13] reported the cases of 2 sisters with BPES, GHD, and an FOXL2 mutation (c.650C > T, p.Ser217Phe) and of another patient with BPES, GHD, and a different FOXL2 mutation (c.672_701dup, p.Ala225_Ala234dup). While these 5 patients presented isolated GHD, the endocrine phenotype of our patients is more variable, from isolated GHD to combined pituitary hormone deficiency (Table 1), suggesting that FOXL2 plays a role in human pituitary deficits in somatotropic, thyrotropic, gonadotropic, and corticotropic cell lines. Patient 2 has isolated partial GHD with no growth retardation. Although a biochemical GH defect is insufficient to confirm GHD or hypopituitarism, here the fact that the MRI data show PSIS proves that the pituitary is affected. GHD is described in the majority of PSIS cases and may evolve with time [26]. Some children with GHD in the context of PSIS maintain a normal growth velocity without any treatment [26].

Several lines of evidence suggest that the congenital hypopituitarism in these probands is the consequence of an FOXL2 signaling defect. FOXL2 is expressed in the hypophysis and it is one of the earliest markers of pituitary differentiation, seemingly being activated by $L H X 3$ nd LHX4 independently of PROP1 [27]. In mice, its role ras mostly been studied in gonadotropic cells [19]. It regulates the expression of the a subunit of the glycoprotein hormone, which is a component of FSH, LH, HCG, and TSH [16]. In humans, FOXL2 is mainly expressed in gonadotropic cells, with a probable influence on their differentiation, but it is also found in thyrotropic cells [28]. While somatotropic expression has never been demonstrated in humans, FOXL2 knockout mice are significantly smaller and present lower levels of insulin-like growth factor 1 (IGF1) [14]. Marongiu et al. [20] recently showed that the GH-IGF1 axis is altered in FOXL2-/- mice. They investigated the effects on male growth of unbalanced female sex hormones and found that the FOXL2 knockout mice were smaller, with a weak pubertal growth spurt, lower IGF1 levels, upregulation of GHRH in the hypothalamus, and downregulation of GHRH-R and GH in the pituitary gland. The location of FOXL2 expression in the hypothalamus and hypophysis was confirmed by polymerase chain reaction (PCR) experiments. Skeletal anomalies (craniofacial and vertebral, with hyperlordosis and hyperkyphosis) were also identified, along with delayed bone and cartilage maturation.

One of the 3 FOXL2 mutations we report here has never been described previously (patient 2). The FOXL2 mutation identified in the family of patient 1 (c.855_871dup) has already been described for patients with both type 1 and type 2 BPES $[14,24,25]$ but with no pituitary phenotype reported. The mutation identified in patient 3 (c.611G $>$ A) was described in 2008 by Beysen et al. [29] in a 1-year-old female patient with sporadic BPES, but her pituitary phenotype was not reported. GnomAD provides constraint metrics that measure how tolerant a gene is to certain classes of variations such as loss-of-function variations. These metrics indicate that FOXL2 has a strong probability of being loss-of-function intolerant and there is no loss-of-function mutation found in "control" populations for this gene. No FOXL2 mutations were found in the remaining 7 patients in our cohort. However, patient 4 has a complete BPES phenotype and patient 5 has blepharophimosis and premature ovarian insufficiency, which are typical signs of an FOXL2 anomaly (no other gene has to date been implicated in this phenotype). Our hypothesis is that they may carry a mutation in the regulatory regions outside FOXL2. Indeed, up to 5\% of patients with BPES show possibly pathogenic variants in distant regions presumed to be cis-regulatory elements [14]. Even if MLPA revealed no large deletions in regions as distant as the ATR gene (up to $6.1 \mathrm{Mb}$ ), we cannot exclude the possible presence of smaller deletions or translocations in regulatory regions distant from the gene. 
A clear genotype-phenotype correlation for FOXL2 mutations is difficult to ascertain. A correlation has nevertheless been proposed, associating mutations producing a protein truncated before the polyalanine tract with BPES type 1 , and those producing a protein with polyalanine expansion with BPES type 2, whereas for missense mutations and mutations leading to a truncated or extended protein containing an intact forkhead domain and polyalanine tract no correlations have been found. $[13,30]$ However, inter- and intrafamilial variability of premature ovarian insufficiency has been described [13]. For families 1 and 2, the type of BPES cannot been determined because in family 1 only males are affected and in family 2 the patient is too young for her ovarian function to be evaluated. Gonadal function is variable in family 3 , with some women having premature ovarian insufficiency (as expected for mutations leading to a deletion of the polyalanine tract) and our patient having hypogonadotropic hypogonadism. Our hypothesis for this family is that BPES type 1 is associated with hypogonadotropic hypogonadism in our patient. Interestingly, some fertility problems, oligomenorrhea, and irregular cycles with no hypergonadotropic hypogonadism have been described in several cases of familial BPES type 2 with mutations leading to a polyalanine tract expansion $[13,29,30]$. These symptoms were explained as possible mild effects of these mutations on ovarian function, giving rise to late-onset ovarian insufficiency [13]. However, another possible explanation is that these patients had hypogonadotropic hypogonadism because of hypopituitarism, as is the case for patient 3 . The fact that for 2 of these patients $[13,29]$ the mutation is the same as the one reported for a patient presenting GHD [13] (c.672_701dup, p.Ala225_ Ala234dup) suggests that this mutation could be involved in hypopituitarism.

Nevertheless, there seems to be no correlation between genotype and pituitary phenotypes. Indeed, the cases that we report involve either a truncated polyalanine tract (patients 2 and 3) or an intact polyalanine tract but completely modified C-terminus (patient 1 ), while the previously reported cases of GH deficiency were the consequence of different FOXL2 changes: a missense mutation in 2 sisters (c.650C $>$ T, p.Ser217Phe) and polyalanine expansion in 1 other patient (c.672_701dup and p.Ala225 Ala234dup) [13].

Furthermore, the siblings in families 1 and 3 with BPES do not have pituitary hormone deficiency. It seems that there is a variable intrafamilial expressivity of FOXL2 in the pituitary phenotype, as has been described for the ovarian phenotype [13]. This variable expressivity of FOXL2 could be the result of interactions with environmental factors and/or oligogenicity, as recently reported for other hypopituitarism features [31], even if no pathogenic variants were identified in the genes analyzed in our series.

About 30 genes have been formally implicated in pituitary deficiencies [4]. Other genes are suspected of involvement in human pituitary pathologies, but the evidence is so far insufficient (limited or disputed) for their inclusion in diagnostic panels according to American College of Medical Genetics and Genomics recommendations [32]. It is therefore possible that our patients' pituitary deficiency was caused by one or several of these genes not included in our panel of 20 genes or by other currently unknown genes. Indeed, molecular causes are only identified in $84-90 \%$ of cases [3, 4$]$, highlighting the role of other factors in this pathology (genes with suspected but so far unproven involvement, unknown genes, and compounding effects of multiple genes). Future investigations will include whole exome sequencing, which has contributed to the discovery of several new genes associated with hypopituitarism in the past few years [4].

The rate of FOXL2 mutations in our population of patients with eyelid anomalies and hypopituitarism ( 3 out of 10 patients) is much higher than previously reported mutation rates for genes associated with hypopituitarism in Western Europe. FOXL2 mutation in our cohort was found only for patients with typical BPES eyelid anomalies, but, again, a variable expressivity seems possible since a pathogenic FOXL2 mutation was recently reported in a woman with moderate ptosis [33]. Further studies are necessary to determine whether FOXL2 should be sequenced in patients presenting hypopituitarism with milder eyelid anomalies.

Since eyelid anomalies are the first signs of this disorder, ophthalmologists should be made aware of possible endocrine involvement. While the need to monitor ovarian function from puberty is now well known, this study highlights the importance of monitoring growth rates earlier in childhood. Pituitary function and hypothalamic-pituitary morphology should be investigated in all patients with BPES, as the results of this study suggest that FOXL2 mutations can affect all pituitary cell lines. In some cases, therefore, this can lead to mixed ovarian insufficiency (i.e., primary and secondary in the same patient), with low LH and FSH levels, as has already been described for the SF1 mutation [34]. 


\section{Conclusion}

This study identifies a possible association between hypopituitarism (ranging from isolated GHD to combined pituitary hormone deficiency) and FOXL2 genetic defects in patients with BPES, suggesting that FOXL2 is involved in human pituitary pathologies. While mice pituitary studies have mostly described the role of FOXL2 in gonadotropic cells, our results suggest its implication in many more pituitary functions, involving all cell lines. This highlights the importance of monitoring both ovarian and pituitary function in BPES patients.

\section{Acknowledgements}

The authors thank Green Grow Scientific for translating and editing the article.

\section{Statement of Ethics}

This study was approved by the local ethics committee (CHU Lyon, No. 19-45). Written informed consent for publication of their clinical details and clinical images was obtained from the parents of the patients.

\section{Disclosure Statement}

The authors declare that there are no conflicts of interests.

\section{Funding Sources}

This research did not receive any specific grant from any funding agency in the public, commercial, or not-for-profit sector.

\section{Author Contributions}

S. Castets designed this study, drafted the initial version of this paper, collected data, coordinated and supervised data collection, analyzed the data, and reviewed and revised this paper. M. Nicolino conceptualized and designed this study, reviewed the initial version of this paper, collected data, analyzed the data, and reviewed and revised this paper. T. Brue, R. Reynaud, C. Girardin, and C. Villanueva collected data and reviewed and revised this paper. F. Roucher-Boulez, D. Mallet-Motak, A. Saveanu, P. AmatiBonneau, D. Bonneau, and Y. Morel performed genetic analyses and reviewed and revised this paper. All of the authors approved the final version of this paper as submitted and agree to be accountable for all aspects of this work.

\section{References}

1 Castinetti F, Reynaud R, Saveanu A, Barlier A, Brue T. Genetic causes of combined pituitary hormone deficiencies in humans. Ann Endocrinol (Paris). 2012 Apr;73(2):53-5.

2 Reynaud R, Gueydan M, Saveanu A, ValletteKasic S, Enjalbert A, Brue T, et al. Genetic screening of combined pituitary hormone deficiency: experience in 195 patients. J Clin Endocrinol Metab. 2006 Sep;91(9):3329-36.

3 Castinetti F, Reynaud R, Saveanu A, Jullien N, Quentien MH, Rochette C, et al. MECHANISMS IN ENDOCRINOLOGY: an update in the genetic aetiologies of combined pituitary hormone deficiency. Eur J Endocrinol. 2016 Jun;174(6):R239-47.

4 Fang Q, George AS, Brinkmeier ML, Mortensen AH, Gergics P, Cheung LY, et al. Genetics of Combined Pituitary Hormone Deficiency: Roadmap into the Genome Era. Endocr Rev. 2016 Dec;37(6):636-75.

5 Dattani MT, Martinez-Barbera JP, Thomas $\mathrm{PQ}$, Brickman JM, Gupta R, Mårtensson IL, et al. Mutations in the homeobox gene HESX1/ Hesxl associated with septo-optic dysplasia in human and mouse. Nat Genet. 1998 Jun; 19(2):125-33.

6 Dateki S, Kosaka K, Hasegawa K, Tanaka H, Azuma N, Yokoya S, et al. Heterozygous orthodenticle homeobox 2 mutations are asso- ciated with variable pituitary phenotype. J Clin Endocrinol Metab. 2010 Feb;95(2):75664.

7 Kelberman D, Dattani MT. The role of transcription factors implicated in anterior pituitary development in the aetiology of congenital hypopituitarism. Ann Med. 2006;38(8): $560-77$.

8 Reynaud R, Jayakody SA, Monnier C, Saveanu A, Bouligand J, Guedj AM, et al. PROKR2 variants in multiple hypopituitarism with pituitary stalk interruption. J Clin Endocrinol Metab. 2012 Jun;97(6):E1068-73.

9 Raivio T, Avbelj M, McCabe MJ, Romero CJ, Dwyer AA, Tommiska J, et al. Genetic overlap in Kallmann syndrome, combined pituitary hormone deficiency, and septo-optic dysplasia. J Clin Endocrinol Metab. 2012 Apr; 97(4):E694-9.

10 Webb EA, AlMutair A, Kelberman D, Bacchelli C, Chanudet E, Lescai F, et al. ARNT2 mutation causes hypopituitarism, post-natal microcephaly, visual and renal anomalies. Brain. 2013 Oct;136(Pt 10):3096-105.

11 Bajuk Studen K, Stefanija MA, Saveanu A, Barlier A, Brue T, Pfeifer M. Genetic analysis of adult Slovenian patients with combined pituitary hormone deficiency. Endocrine. 2019 Aug;65(2):379-85.
12 Heude É, Bellessort B, Fontaine A, Hamazaki M, Treier AC, Treier M, et al. Etiology of craniofacial malformations in mouse models of blepharophimosis, ptosis and epicanthus inversus syndrome. Hum Mol Genet. 2015 Mar; 24(6):1670-81.

13 Beysen D, De Paepe A, De Baere E. FOXL2 mutations and genomic rearrangements in BPES. Hum Mutat. 2009 Feb;30(2):158-69.

14 Crisponi L, Deiana M, Loi A, Chiappe F, Uda M, Amati P, et al. The putative forkhead transcription factor FOXL2 is mutated in blepharophimosis/ptosis/epicanthus inversus syndrome. Nat Genet. 2001 Feb;27(2): 159-66.

15 Uda M, Ottolenghi C, Crisponi L, Garcia JE, Deiana M, Kimber W, et al. Foxl2 disruption causes mouse ovarian failure by pervasive blockage of follicle development. Hum Mol Genet. 2004 Jun;13(11):1171-81.

16 Nicolino M, Bost M, David M, Chaussain JL. Familial blepharophimosis: an uncommon marker of ovarian dysgenesis. J Pediatr Endocrinol Metab. 1995 Apr-Jun;8(2):127-33.

17 Dawson EL, Hardy TG, Collin JR, Lee JP. The incidence of strabismus and refractive error in patients with blepharophimosis, ptosis and epicanthus inversus syndrome (BPES). Strabismus. 2003 Sep;11(3):173-7. 
18 Verdin H, De Baere E. Blepharophimosis, Ptosis, and Epicanthus Inversus. In: Pagon $\mathrm{RA}$, Adam MP, Ardinger HH, Wallace SE, Amemiya A, Bean LJ, et al., editors. GeneReviews $\left({ }^{\circledR}\right)$. Seattle (WA). Seattle: University of Washington; 1993., Available http://www. ncbi.nlm.nih.gov/books/NBK1441/

19 Davis SW, Ellsworth BS, Peréz Millan MI, Gergics P, Schade V, Foyouzi N, et al. Pituitary gland development and disease: from stem cell to hormone production. Curr Top Dev Biol. 2013;106:1-47.

20 Marongiu M, Marcia L, Pelosi E, Lovicu M, Deiana M, Zhang Y, et al. FOXL2 modulates cartilage, skeletal development and IGF1-dependent growth in mice. BMC Dev Biol. 2015 Jul;15(1):27.

21 Wales JK. Concerning the article by Ogata et al. Hypergonadotrophic hypogonadism in a 3-year-old girl with blepharophimosis, ptosis, and epicanthus inversus syndrome. Horm Res. 1998;50(6):341.

22 Varghese B, Donnai D, Shalet S. Isolated growth hormone deficiency and BPES. 2002 [cited 31 Jan 2018]. Available: http://www.endocrine-abstracts.org/ea/0003/ea0003p13.htm

23 Richards S, Aziz N, Bale S, Bick D, Das S, Gastier-Foster J, et al.; ACMG Laboratory Quality Assurance Committee. Standards and guidelines for the interpretation of sequence variants: a joint consensus recommendation of the American College of Medical Genetics and Genomics and the Association for Molecular Pathology. Genet Med. 2015 May;17(5):405-24.
24 Udar N, Yellore V, Chalukya M, Yelchits S, Silva-Garcia R, Small K; BPES Consortium. Comparative analysis of the FOXL2 gene and characterization of mutations in BPES patients. Hum Mutat. 2003 Sep;22(3):222-8.

25 Yamada T, Hayasaka S, Matsumoto M, Budu, Esa T, Hayasaka Y, et al. Heterozygous 17-bp deletion in the forkhead transcription factor gene, FOXL2, in a Japanese family with blepharophimosis-ptosis-epicanthus inversus syndrome. J Hum Genet. 2001;46(12):733-6.

26 Vergier J, Castinetti F, Saveanu A, Girard N, Brue T, Reynaud R. DIAGNOSIS OF ENDOCRINE DISEASE: Pituitary stalk interruption syndrome: etiology and clinical manifestations. Eur J Endocrinol. 2019 Nov;181(5): R199-209.

27 Ellsworth BS, Egashira N, Haller JL, Butts DL, Cocquet J, Clay CM, et al. FOXL2 in the pituitary: molecular, genetic, and developmental analysis. Mol Endocrinol. 2006 Nov;20(11): 2796-805.

28 Egashira N, Takekoshi S, Takei M, Teramoto A, Osamura RY. Expression of FOXL2 in human normal pituitaries and pituitary adenomas. Mod Pathol. 2011 Jun;24(6):765-73.

29 Beysen D, De Jaegere S, Amor D, Bouchard P, Christin-Maitre S, Fellous M, et al. Identification of 34 novel and 56 known FOXL2 mutations in patients with Blepharophimosis syndrome. Hum Mutat. 2008 Nov;29(11):E205-19.
30 De Baere E, Dixon MJ, Small KW, Jabs EW, Leroy BP, Devriendt K, et al. Spectrum of FOXL2 gene mutations in blepharophimosisptosis-epicanthus inversus (BPES) families demonstrates a genotype-phenotype correlation. Hum Mol Genet. 2001 Jul;10(15): 1591-600.

31 McCormack SE, Li D, Kim YJ, Lee JY, Kim SH, Rapaport R, et al. Digenic Inheritance of PROKR2 and WDR11 Mutations in Pituitary Stalk Interruption Syndrome. J Clin Endocrinol Metab. 2017 Jul;102(7):2501-7.

32 Bean LJ, Funke B, Carlston CM, Gannon JL, Kantarci S, Krock BL, et al. Diagnostic gene sequencing panels: From design to report - A technical standard of the American College of Medical Genetics and Genomics (ACMG). Genet Med Off J Am Coll Med Genet. 2020 Mar;22(3):453-461

33 Krepelova A, Simandlova M, Vlckova M, Kuthan P, Vincent AL, Liskova P. Analysis of FOXL2 detects three novel mutations and an atypical phenotype of blepharophimosis-ptosis-epicanthus inversus syndrome. Clin Exp Ophthalmol. 2016 Dec; 44(9):757-62.

34 Zhao L, Bakke M, Krimkevich Y, Cushman LJ, Parlow AF, Camper SA, et al. Steroidogenic factor 1 (SF1) is essential for pituitary gonadotrope function. Development. 2001 Jan; 128(2):147-54. 